3 年間閉鎖しない, 放射線肺臓炎の肺切除断端に生じた難治性術後肺瘦

\author{
中島 由貴*1, 秋山 博彦*1, 木下 裕康*1 \\ 飯島 慶仁*1, 小泉 潔*2, 浦本 秀隆*1
}

\begin{abstract}
要 旨
放射線肺臓炎を来たした肺を手術時にどのように扱うかを論じた報告は極めて少ない. 症例は 65 歳男性. 胸腺癌・正岡分 類 IV 期の診断で化学放射線療法と脳転移に対して $\gamma$ ナイフを施行した．原発巣縮小，脳転移は消失したため手術を施行し た。胸腺と共に腫瘍を摘出，壁側胸膜と左肺上葉を部分合併切除した，その際放射線肺臟炎領域より気瘻を認め縫合閉鎖し た. 術後 90 日目に左胸水の減少あり左胸胿ドレーンを挿入した所, 気瘦を認めた。術後 120 日目に手術施行, 放射線肺臟炎 領域に瘦孔を認め肋間筋にて被覆した。術後 3 年無再発生存中であるが, 経過中 2 回, 発熱・呼吸困難感と共に左胸水が減 少するエピソードがあり未だに瘦孔は閉鎖していないと考えられる．放射線肺臟炎領域は血流の低下により創傷治癒機転と 免疫が著しく低下していると考えられ, 放射線肺臟炎領域からの肺㾇は入念な修復が必要であり, 筋弁や心膜脂肪織での被 覆が望ましいと考えた.
\end{abstract}

索引用語：胸腺癌, 化学放射線療法, 放射線肺臟炎, 難治性肺癭, 手術 thymic cancer, chemoradiotherapy, radiation pneumonitis, refractory pulmonary fistula, surgical treatment

\section{はじめに}

局所進行肺癌や縱隔腫瘍に対する放射線治療後の手術 において，気管支断端被覆に関する報告は多いが放射線 肺臟炎を来たした肺をどのように扱うかを論じた報告は 極めて少ない. 今回我々は正岡分類 IVb 期の胸腺癌に対 して化学放射線療法後に手術を行ったが, 放射線肺炎領 域からの肺瘦が術後 3 年を経過しても閉鎖していないと 考えられる症例を経験したので 2 回の手術の改善点を過 去の報告を含め検討し報告する.

\section{症例}

症 例：65 歳 男性.

\footnotetext{
*1埼玉県立がんセンター胸部外科

*2会津中央病院呼吸器外科

原稿受付 2015年11月19日

原稿採択 2016年 2 月 6 日

本論文の要旨は第 33 回日本呼吸器外科学会総会にて発表し た.
}

主 訴: 易疲労感, 左前胸部痛.

既往歴：特記事項なし.

喫煙歴：20 本/日， 42 年間.

職 業: 夕イヤ関連営業.

現病歴 : 易疲労感と左前胸部痛を自覚して近医を受診 した. 胸部 CTにて前縦隔腫瘍を指摘され当院紹介と なった。

初診時理学所見: 身長 $174 \mathrm{~cm}$, 体重 $54 \mathrm{~kg}$, 脈拍 113/ 分, 体温 $37.3^{\circ} \mathrm{C}, \mathrm{SpO} 293 \%$ (room air).

血液検査所見 : CRP $13.2 \mathrm{mg} / \mathrm{dl}, \mathrm{HCG} 1.3 \mathrm{mIU} / \mathrm{ml}$, 可 溶性 IL-2 受容体 $953 \mathrm{U} / \mathrm{ml}$ と上昇を認めた。 その他の腫 瘍マーカー, AFP, CEA, ProGRP, CYFRA は基準值内 であった。

胸部 CT 所見：前縦隔から左胸腔内に長径 $98 \mathrm{~mm}$ の 辺縁明瞭な腫瘤影を認めた (Fig. 1b).

脳 MRI 所見 : 左前頭部に径 $8 \mathrm{~mm}$ の周囲に浮腫を伴 う結節病変を認めた（Fig. 1a）。

腫瘍生検病理組織所見：類円形の悪性細胞を認める. 角化傾向や腺腔形成は明らかでない, 免疫染色結果は 

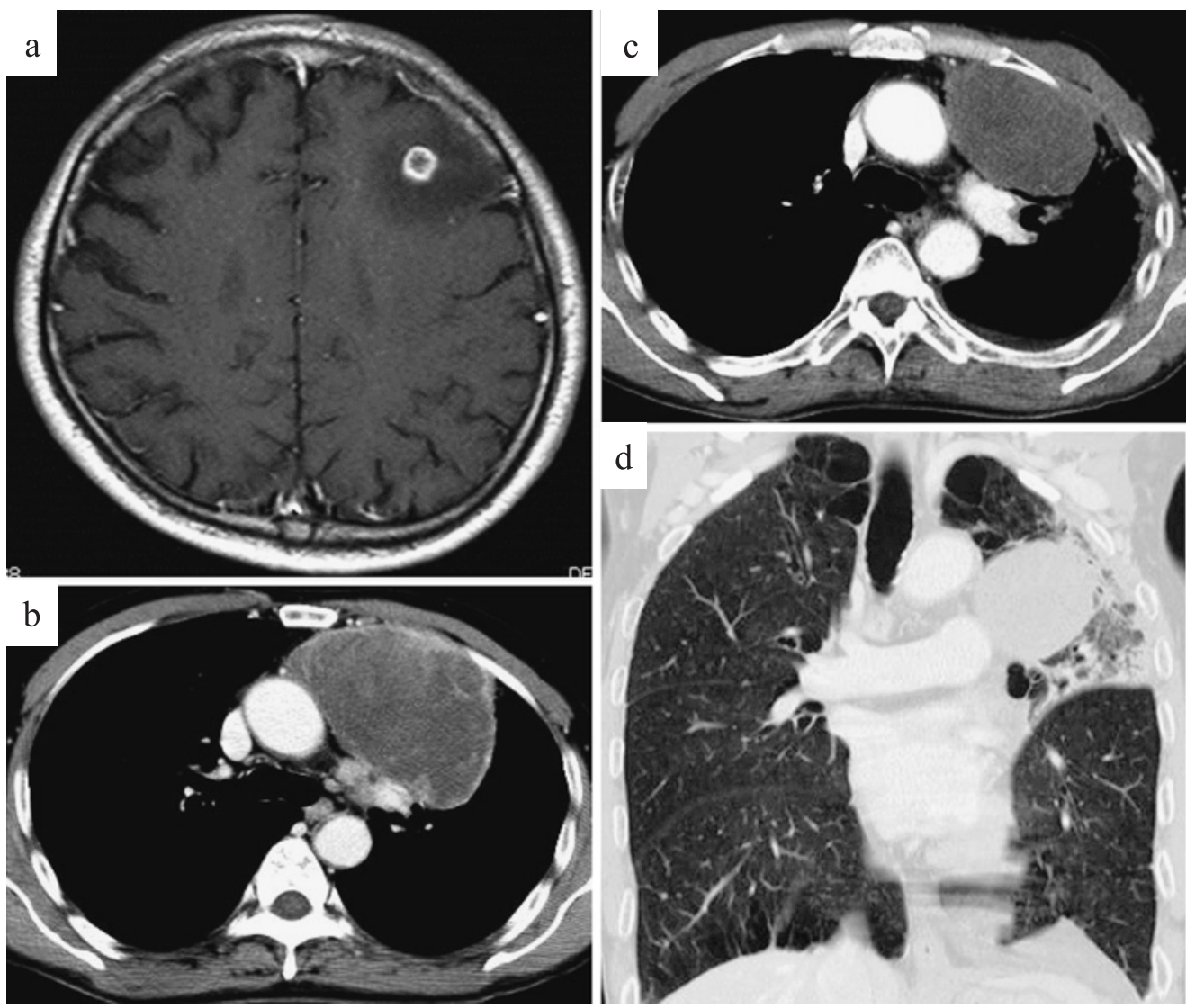

Fig. 1 a) Contrast-enhanced brain CT before treatment. A tumor shadow was present in the frontal lobe on the left side of the brain, at $8 \mathrm{~mm}$ in diameter. b) Contrast-enhanced chest CT before treatment. A tumor shadow with a long diameter of $98 \mathrm{~mm}$ was present from the anterior mediastinum to the left pleural space. c) Contrast-enhanced chest CT postchemoradiotherapy. The tumor shadow was reduced to $77 \mathrm{~mm}$. d) Preoperative chest CT shows radiation pneumonitis in the left upper lobe.

CD5， c-kit，CAM5.2，AE1/3 が陽性，vimentin，LCA， TTF-1, NapsinA, CD56, synaptophysin, chromogranin A, bcl-2 が陰性であった. 以上から胸腺癌と診断された (Fig. 2a, b).

治療経過 : 以上の結果より胸腺癌, 正岡 IVb 期と診断 された，原発巣に対しては化学療法 CDDP +ETP 4 コー ス，また前胸部痛があり胸壁浸潤が疑われることから同 時期に放射線治療 $60 \mathrm{~Gy}$ を行った。脳転移に対してはガ ンマナイフを行った。治療効果は, 原発巣は腫瘍径 104 $\mathrm{mm} \rightarrow 77 \mathrm{~mm}$ と縮小して SD (Fig. 1c), 脳転移はガンマナ イフ施行後 3 カ月で消失した。新たな転移の出現無く, 病勢はコントロールされていると判断し手術の方針とし た. 放射線治療終了後 8 週間を経過して左肺上葉に浸潤 影が出現し， $37^{\circ} \mathrm{C}$ 台の発熱と CRP の上昇を認めた (Fig. 1d）。放射線照射野に一致するため放射線肺臟炎を第一
に考えたが，化学療法施行中であり感染の可能性も考え て抗生物質レボフロキサシンを 2 週間投与した。解熱し て CRP も低下したが, 肺浸潤影は若干改善したものの依 然として残存しており放射線肺臓炎と診断した。

初回手術所見：放射線治療終了後 101 日, 抗癌剂治療 終了後 66 日目に手術施行. 胸骨正中切開と第 3 肋間で胸 骨を横切して開胸する L 字切開でアプローチした．胸腺 と共に腫瘍を摘出した，癒着は強固であったが心膜，肺 門部からは剥離可能であった，胸壁側は壁側胸膜を合併 切除, 肺との癒着も強固であり肺部分合併切除を行った。 肺は放射線肺臟炎の影響で組織が脆弱になっていた。肉 眼的には線維化, 浮腫を来たしている状態で自動縫合器 を使用できる状況ではなかった。腫瘍とのマージンを確 保して電気メスにて切離した。肺切離断端は非吸収性モ ノフィラメント糸で縫合閉鎖し，フィブリン糊を散布し 

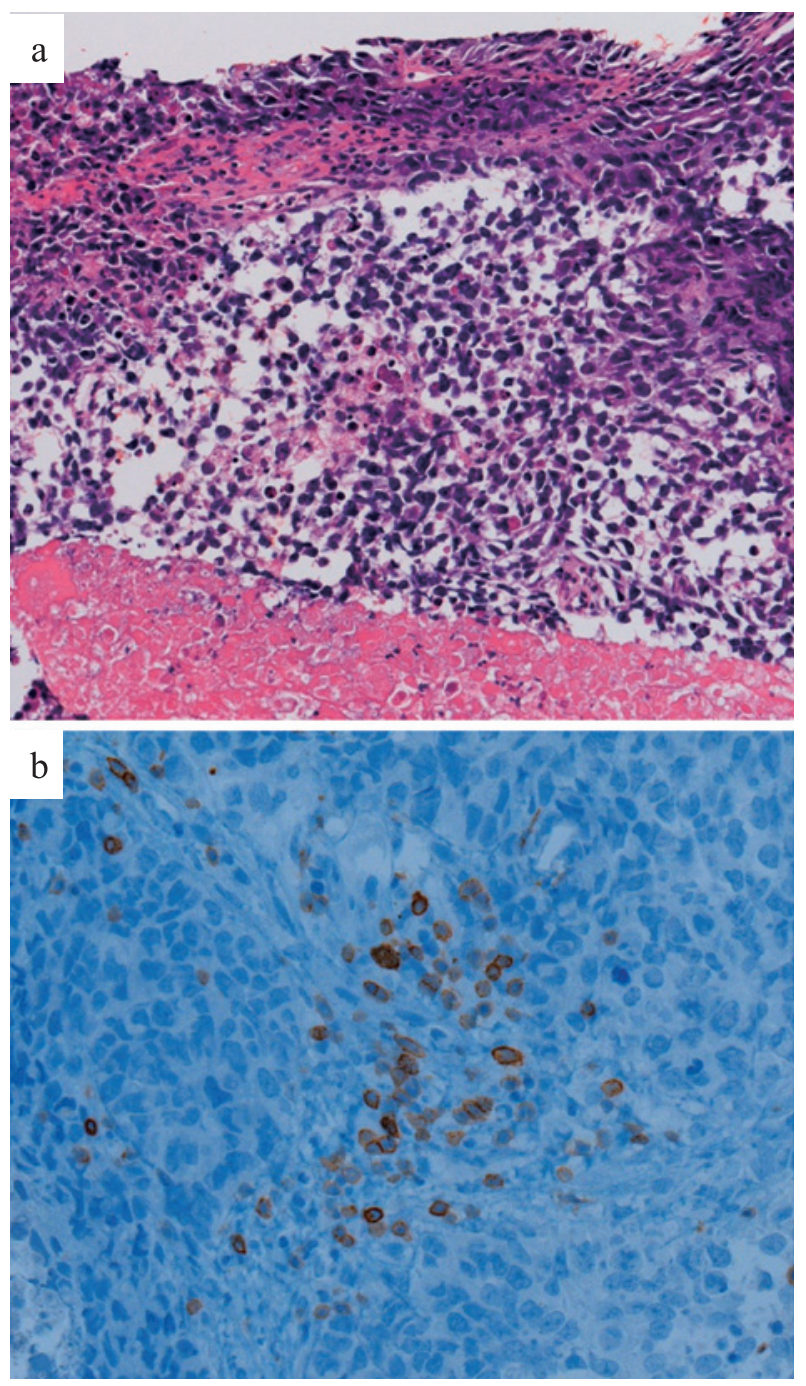

Fig. 2 a) Hematoxylin and eosin-stained biopsy of the tumor. The solid growth of suborbicular malignant cells was confirmed, and a tendency for cornification and the formation of a gland duct were unclear. b) The tumor cells were positive for CD5.

た. 肺切除断端縫合前はシーリングテストで気瘻を認め たが，縫合後は気瘦を認めなかった。手術時間 228 分, 出血量 $1931 \mathrm{ml}$ であった。

病理組織学的所見：胸腺内に $70 \times 50 \mathrm{~mm}$ 大の黄灰白 色調の充実性腫瘤が存在する。腫瘤は壊死組織からなり 周囲に炎症細胞浸潤や線維化がみられる。 viable cell な L.

初回術後経過：術後は肺㾇が遷延した. 15PODに胸腔 ドレーン抜去, 17POD に退院した. 72POD に発熱, 呼吸 困難感が出現, 胸部レントゲン写真にて右上葉に浸潤影 を認め肺炎と診断, 抗生剂投与を開始した. 90POD に血
液検査で白血球 $14220 / \mu \mathrm{l}, \mathrm{CRP} 17.2 \mathrm{mg} / \mathrm{dl}$ と再上昇を 認め, 胸部レントゲン写真で左胸腔に貯留していた胸水 の減少がみられた（Fig. 3a， b) 。吸入性肺炎を疑い左胸 腔ドレーンを挿入したところ少量の気瘦を認めた．胸部 CT では肺表面に明らかな気管支の露出はみられず放射 線肺臓炎領域からの肺瘦が原因と判断した。胸水は淡血 性で培養は 2 回陰性であった。気瘻は止まらず $122 \mathrm{POD}$ 手術を施行した。

2 回目手術所見：胸腔内は白苔に覆われており膿胸様 の所見であった．気瘻は肺表面の $1 \mathrm{~mm}$ 大の小孔より認 められた。肺は硬化しており縫合閉鎖は困難であると判 断して肋間筋を採取し瘦孔を被覆して周囲を固定した。

2 回目術後経過 : 術後も胸腔ドレーンより気瘦が続い たが7POD に消失し 9POD ドレーン抜去，15POD 退院 した。 その後外来通院中に, 初回手術後 24 力月と 32 力 月の 2 回, 発熱と呼吸困難感を認めた。その際の血液検 查所見では, 白血球と CRP の上昇を認め, 直近の胸部レ ントゲン写真と比較して左胸水の減少がみられた（Fig. 3c，d）。いずれも抗生剂内服で軽快している。初回術後 から 3 年, 胸腺癌は無再発, 難治性肺瘦に関して外来経 過観察中である.

\section{考察}

本症例は術後 3 年を経過しても時に左胸水の減少を認 めることから，未だに放射線肺臓炎領域の瘻孔は閉鎖し ていないと考えられる。放射線治療による肺障害には急 性期の放射線肺臓炎と慢性期の放射線線維症が含まれ る ${ }^{1}$. 放射線肺臓炎の発生機序として肺胞上皮の $90 \%$ 以 上を占める I 型肺胞上皮細胞のアポトーシスが起こり引 き続いて前駆細胞である II 型肺胞上皮細胞の急速な増 殖が起きるとされている. II 型肺胞上皮は界面活性物質 の産生細胞であり, 界面活性物質の増加がみられる。 ま た毛細血管内皮細胞も障害をうけるとされる ${ }^{2,3)}$. Warren らは放射線照射による肺実質の病理学的な変化として, 肺胞壁の浮腫と炎症細胞浸潤, 肺胞上皮の過形成, 肺胞 壁の硝子膜形成と線維化, 毛細血管の硝子化を挙げてい る . 毛細血管の障害は組織の虚血と低酸素症に繋がり局 所の免疫や創傷治癒能力を著しく低下させる ${ }^{5}$. 岩崎らは 術後 $4,72,84$ 力月を経過して発症した晚発生膿胸 3 例 に関して, 膿胸は放射性肺臟炎領域に一致して発症して おり成因の一つであると報告している ${ }^{6}$. また Hirataら は術後 8 年を経過して放射線線維症領域に一致して発症 

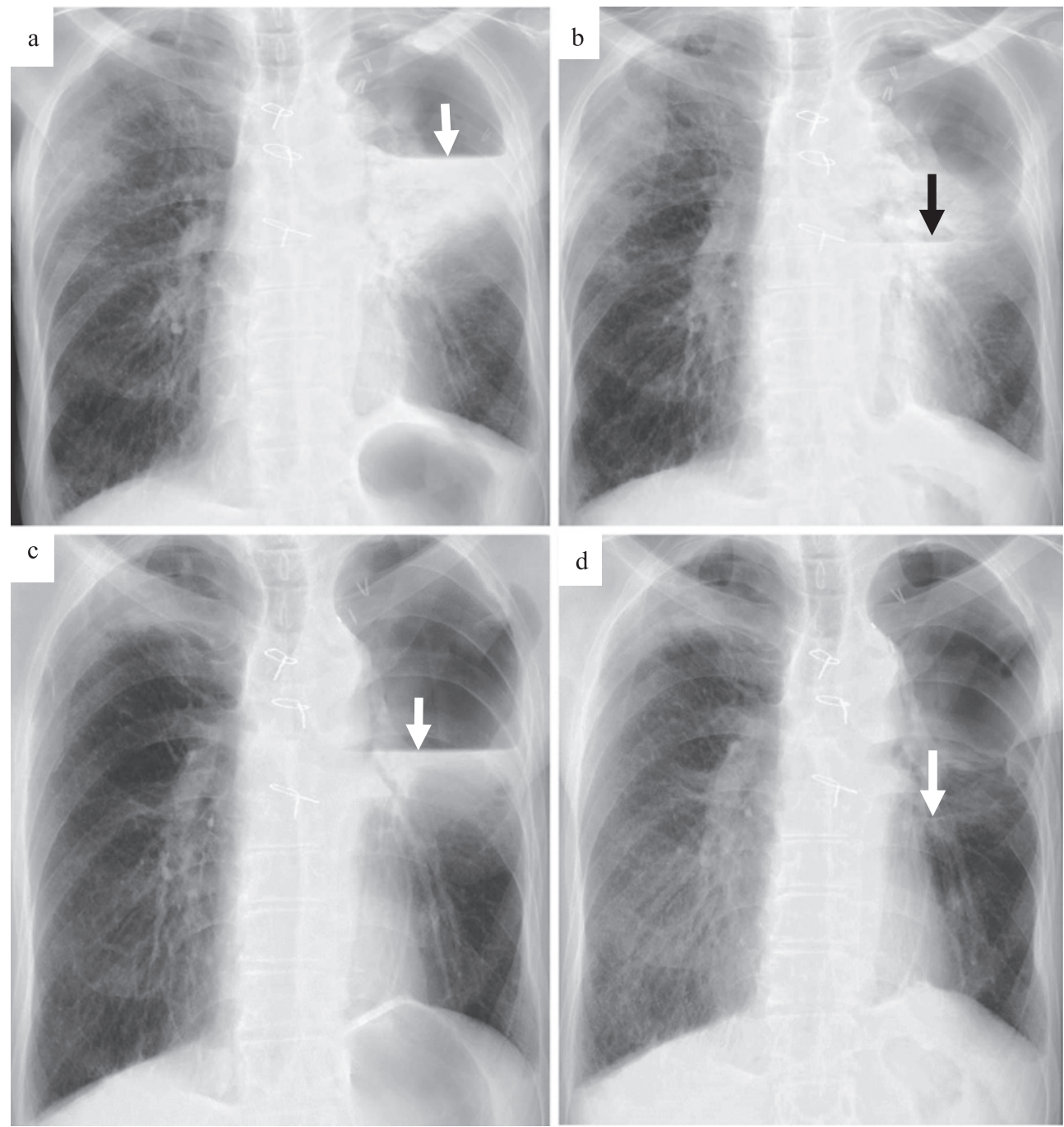

Fig. 3 a) Chest radiograph on POD 87 shows left pleural effusion (white arrow). b) Chest radiograph on POD 90 shows reduction of the left pleural effusion compared with a) (black arrow). Consolidation is apparent in the right upper lobe. c) Chest radiograph at 20 months after first surgery shows left pleural effusion (white arrow). d) Chest radiograph at 24 months after the first surgery shows reduction of the left pleural effusion compared with a) (white arrow).

した膿胸を報告している7. 両者ともに切除した放射線肺 臓炎肺の所見は, 脈管組織に極めてそしい線維性に肥厚 した胸膜と単核円形細胞の浸潤であった。

これらの事から考えられることは，放射線肺㵴炎領域 は血流が忘しく，低酸素状態であり免疫や創傷治癒機転 は年単位で回復しないという事である。よって放射線肺 臓炎領域に手術操作を加える事はなるべく避けたほうが 望ましい，本症例は腫瘍からのマージンを確保するため にやむなく肺部分合併切除術を行った. 左肺上葉の大部 分は放射線肺臓炎を来たしていたため左肺上葉切除術も
考慮した。しかし上葉気管支は放射線照射野に含まれて おり，気管支断端瘦という更に重篤な合併症を来たす可 能性があり肺部分切除に留めた ${ }^{8)}$. 本症例初回手術のよう に放射線肺臓炎肺を切除せざるを得ない機会もあるた め, 肺切除断端からの気漏が認められる場合は特に入念 に修復を行うべきであると考えられる。

また肺瘻が遷延し，慢性化した第二の原因として肺の コンプライアンス低下と死腔の存在が挙げられる。本症 例は，放射線肺線維症を来たしたことから肺コンプライ アンスが低下し再膨張が不良となり，腫瘍摘出部分に死 
腔が生じた。 その結果, 肺内と死腔との圧格差が生じて 胸膜の修復を更に妨げている可能性が高い9).

一般に, 術後肺瘦の閉鎖方法は保存的手法と外科的手 法に大別される. 保存的手法には, 主に胸腔ドレーンか らの OK432, テトラサイクリン, 自己血やフィブリン糊 の注入療法が挙げられる ${ }^{10-12)}$. これらは壁側胸膜と肺の癒 着を目的とした治療であり, 本症例のような死腔が残存 した症例には適さないと考えられる。また近年 Endobronchial Watanabe Spigot（EWS）を用いた経気管支 的な気管支充填術が広まりつつあり, 難治性肺瘦に対す る治療として期待される ${ }^{13}$. 一方外科的手法としては, 直 接縫合, フィブリン糊の塗布や人工物による被覆, 心膜 脂肪織・筋弁・大網などの自己組織による被覆が挙げら れる ${ }^{14-16)}$. 特に自己組織による被覆は難治性肺瘻に対して 行われている例が多い。これらの事から, 初回手術時も 自己組織による被覆にて術後肺瘦を防ぐことが出来た可 能性がある。また 2 回目の手術時において, 直接縫合は 組織が硬化していたため困難であった。また前述の通り 正常な創傷治癒機転が期待できない場合, 自然吸収され るフィブリン糊や人工物による被覆も確実性にそしいと 考えられる. 我々は肋間筋弁による被覆を行ったが, 症 状緩和は出来たものの未だ瘦孔閉鎖に至っていない.し かし初回手術から 3 年の経過で, 炎症の再燃を 2 回認め ているものの, 抗生剤内服により改善しているため経過 観察中である. 今後同様のエピソードが頻回に繰り返さ れる場合は, 前述の報告を参考に EWS を用いた気管支 充填, もしくは自己組織による被覆に加えて死腔の閉鎖 も考慮すべきであると考えた。また過去の報告のよう $に^{6.7)}$, 今後膿胸を来たす可能性もあり注意深い観察が必 要である。

\section{結語}

放射線肺臓炎領域からの肺瘦が術後 3 年を経過しても 閉鎖していないと考えられる症例を経験した．放射線肺 臓炎領域は血流の低下により創傷治癒機転と免疫が著し く低下していると考えられ, 放射線肺蔵炎領域からの肺 瘦は入念な修復が必要であり筋弁や心膜脂肪織での被覆 が望ましいと考えた。

\section{利益相反}

本論文に関して申告する利益相反はない.

\section{文献}

1. Seppenwoolde Y, Lebesque JV. Partial irradiation of the lung. Semin Radiat Oncol 2001; 11: 247-58.

2. Prakash UB. Radiation-induced injury in the "nonirradiated" lung. Eur Respir J 1999; 13: 715-7.

3. Tsoutsou PG, Koukourakis MI. Radiation pneumonitis and fibrosis: mechanisms underlying its pathogenesis and implications for future research. Int J Radiat Oncol Biol Phys 2006; 66: 1281-93.

4. Warren S, Spencer J. Radiation reaction on the lung and bronchial tree. Am J Roentgenol 1940; 43: 682-70.

5. Miller SH, Rudolph R. Healing in the irradiated wound. Clin Plast Surg 1990; 17: 503-8.

6. 岩崎正之, 小川純一, 井上宏司, 正津 晃, 母里知之. 肺 癌手術後晚発性膿胸症例の検討. 肺癌 1990; 30: 255-9.

7. Hirata S, Akaike Y, Seki K, Kawaguchi K. A case if Surgically cured lung abscess: Originating from postoperative radiation fibrosis because of $\mathrm{T} 3$ cases of lung cancer 8 years ago. Jpn J Thorac Surg 1985; 38: 823-6.

8. 山本良二, 多田弘人, 貴志彰宏, 東条 尚, 麻田博輝. 気 管支粘膜血流に対する術前放射線化学療法の影響. 日呼 外会誌 2001; 15: 459-64.

9. 中島 淳. 浅野ら “気腫性肺に対する複数回の手術後に生 じた難治性肺瘦に対し EWS が奏功した 1 例”。気管支学 2015; 37: 373-4.

10. Stephenson LW. Treatment of pneumothorax with intrapleural tetracycline. Chest 1985; 88: 803-4.

11. Dumire R, Crabbe MM, Mappin FG, Fontenelle LJ. Autologous 'blood patch' pleurodesis for persistent pulmonary air leak. Chest 1992; 101: 64-6.

12. Kinoshita T, Miyoshi S, Katoh M, Yoshimasu T, Juri M, Maebeya S, et al. Intrapleural administration of a large amount of diluted fiblin glue for intractable pneumothorax. Chest 2000; 117: 790-5.

13. 渡辺洋一, 松尾圭祐, 玉置明彦, 平木俊吉, 森山重治, 堀 内武志. 難治性気胸, 気管支瘦に対する EWS(Endobronchial Watanabe Spigot）を用いた気管支充填術の有用性. 気管支学 2001; 23: 510-5.

14. Yoshimura M, Tsubota N, Matsuoka H, Sakamoto T. Efficacy of a pedicled pericardial fat pad fixed with fibrin glue on postoperative alveolar air leakage. Surg Today 
2002; 32: 26-8.

15. 高橋正彦, 石井泰則, 井上文之. 有茎肋間筋弁による被覆 が有用であった荒罴肺に合併した遷延性気胸の 1 例. 日 呼外会誌 2008; 22: 55-8.
16. 倉橋康則, 大久保憲一, 里田直樹, 宮本信宏, 岡本俊宏, 五十部潤, 他. 難治性肺瘦に対して有茎大網被覆により治 癒した 2 例. 日呼外会誌 2000; 14: 797-802.

\title{
Case report of a refractory pulmonary fistula in the region of radiation pneumonitis for 3 years after surgery
}

\author{
Yuki Nakajima*1, Hirohiko Akiyama*1, Hiroyasu Kinoshita*1 \\ Yoshihito Iijima*1, Kiyoshi Koizumi*2, Hidetaka Uramoto*1 \\ ${ }^{* 1}$ Department of Thoracic Surgery, Saitama Cancer Center \\ ${ }^{* 2}$ Department of Thoracic Surgery, Aidu Chuo Hospital
}

Reports of treatment methods during surgery for the lungs with radiation pneumonitis have been rare. The case was a 65-year-old male patient who was diagnosed with stage IV thymic cancer based on the Masaoka classification. He underwent 4 courses of CDDP+ETP and gamma knife treatment for cerebral metastasis. After a decrease in the size of the primary lesion and disappearance of the cerebral metastasis were confirmed, surgery was performed to remove the remaining tumor together with the thymus gland and to partially excise the parietal pleura together with the left upper lobe. During the surgery, an aerial fistula was confirmed in the region of radiation pneumonitis and was closed with stitches. On postoperative day 90, when a left thoracostomy tube was inserted to examine the decrease in left pleural fluid, an aerial fistula was confirmed. During surgery on postoperative day 120 , a fistula was observed in the region of radiation pneumonitis, and was covered with intercostal muscle. Although the patient survived for 3 years after the surgery, 2 episodes involving a decrease in left pleural fluid, fever, and a sensation of dyspnea were confirmed during the follow-up observation, suggesting that the fistula had not closed. In the region of radiation pneumonitis, wound healing and immunity are markedly reduced due to a decrease in blood flow. Therefore, a pulmonary fistula in the region of radiation pneumonitis requires careful repair, and it is recommended that such a fistula be covered with either a muscle flap or pericardial adipose tissue. 